\title{
フレキシブルデバイス用 PEN フィルム
}

\section{1.はじめに}

PEN フィルムとは，2，6 ナフタレンジカルボン酸とエ チレングリコールを重縮合した結晶性ポリエステルである ポリエチレン 2,6 -ナフタレートを二軸延伸して製造され るフィルムである. PEN フィルムは, その素材の持つ, 優れた耐熱性, 強度, 剛性, 耐薬品性, ガスバリア性など の強みを生かし，これまでに磁気記録テープ基材，写真用 基材, 電気絶縁材料, コンデンサー, FPC, メンブレンタッ チスイッチ, 各種工程材料など幅広い用途・分野に採用さ れており, 現在さらにその用途拡大を検討している ${ }^{1)}$. 対 象となる新規用途のひとつには，フレキシブルデバイス用 途などがある.フレキシブルデバイス用途としては, フレ キシブルディスプレイ, フレキシブル太陽電池, フレキシ ブルセンサーなどが挙げられる. 中でもフレキシブルディ スプレイは Polymer Vision やPlastic Logicなどが 2008 年度中の商業化を発表しており注目を集めている。これら フレキシブルデバイスでは極めて高い表面平滑性，透明性， 及びフォトリソグラフィーのような $150^{\circ} \mathrm{C}$ を超える温度で の高い寸法安定性が要求されている.

ここでは, 新規に開発したフレキシブルデバイス用 PEN フィルムの特性を成形プロセスで形成される構造や設計思 想から説明し, 最後に今後の開発動向と課題について報告 する。

\section{2. ポリエステルフィルムの製造工程と構造発現}

図 1 はポリエステルフィルムの一般的な溶融押出 -2 軸 延伸のプロセスである. 口金からシート状に溶融押出され た樹脂は球晶の発生を抑制するために直ちに急冷され，そ の後再加熱して一方向に延伸され, さらに直角方向に延伸 された後に定長で熱処理をされてから巻き取られる.

このプロセス中においてフィルムを形成する高分子の構 造, 特に分子鎖の配向と結晶状態を制御し, その程度に応 じてフィルムとしたときのさまざまな物性を制御すること が可能である. 一例を挙げると，図 2 a）に示すように 2 軸延伸による分子鎖の配向を制御することによりフィルム の弾性率を飛躍的に向上させることができ，また，図 2 b)

\footnotetext{
* Hashimoto, Katsuyuki

帝人デュポンフィルム侏）基盤技術開発部

岐阜県安八郡安八町南條 1357 ( ₹ 503-0123)

2007.11.21 受理
}

に示すように熱澎張係数がきわめて小さいフィルムを製造 することができる。ささらに，図 $2 \mathrm{c} ）$ に示すように，結晶 状態を制御することにより，フィルムの水蒸気透過率を向 上させることが可能である.フィルムのみならず繊維も含 めて紡糸・延伸過程での配向結晶化などの構造形成はまだ 完全には解明しきれていないのが現状であるが，大型放射 光設備などの手段も含む数多くの研究がなされつつあり, 今後の進展が期待される実用上重要な分野のひとつである と考える ${ }^{2) \sim 5)}$.

\section{3．高透明耐熱 PEN フィルム}

\section{1 透明性・表面性設計}

通常の PEN フィルムは加工工程でのハンドリング性を 容易にするためにフィルム中に粒子を入れてフィルム表面 に突起を形成させるが，このような粒子は光を散乱させる 因子となり透明性は損なわれてしまうことになる。また， 表面に突起があるとバリア膜やデバイス素子の加工時にそ こがデイスプレイの欠陷になってしまう。 ハンドリング性 と透明性, 表面平坦性を両立させるための方策は種々考え られるが, 最も簡便な方法としては少なくとも片面にコー ティングなどで突起を形成させる方法がある.このコー ティング層には, ハンドリング性を向上させるための粒子 を添加する以外にも, 種々の機能膜や色素, インクなどを フィルム上に積層・印刷する場合に，各々の膜に応じた接 着性を向上させる機能をもたせることや, 帯電防止性能な どを同時に付与することも可能である.このようなコー ティング技術との組み合わせにより, 従来の PEN フィル ムよりも透明性に優れ, かつ表面平滑性にも優れた高透明 PENフィルムを開発した.

\section{2 一般物性設計}

水蒸気を含むガスバリア性, 耐薬品性, 耐衝撃性, 寸法 安定性, 力学強度などは, 高分子構造と密接な関係にある. 図 3 は分子配向を制御したときのフィルムのヤング率と熱 膨張係数, 湿度膨張係数との関係をプロットしたものであ る。一般に配向した高分子鎖では，分子鎖が伸びきってい る場合，熱振動により分子鎖軸に垂直な方向では膨張する が, 分子鎖方向では収縮する. 分子鎖の配向状態と結晶化 度を成形工程で制御することにより，広い範囲にわたって 膨張係数の制御が可能となる。 さらに熱収縮に関しては, 上記構造制御の一方法であるが, 延伸一熱処理したフィル ムを再度熱処理することできわめて低いレベルにまで低減 


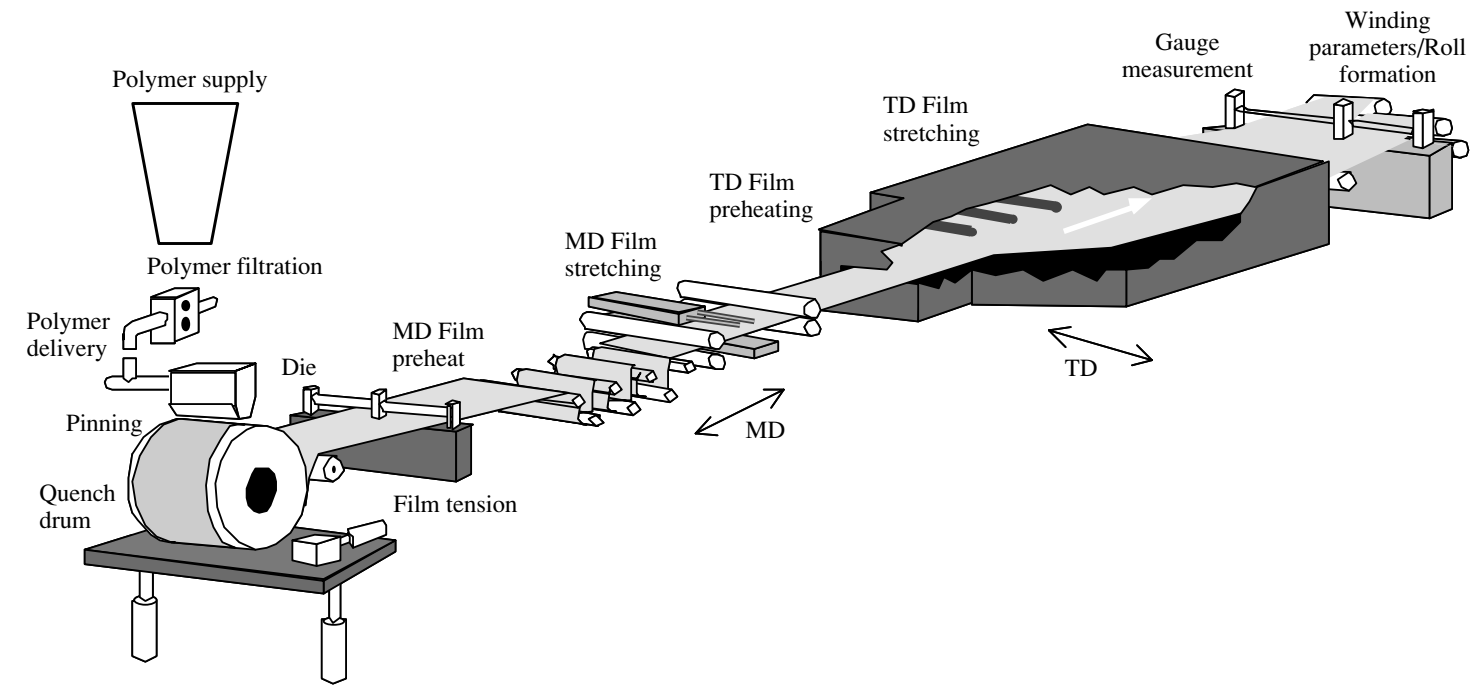

図 1 溶融押出しフィルムの製造方法

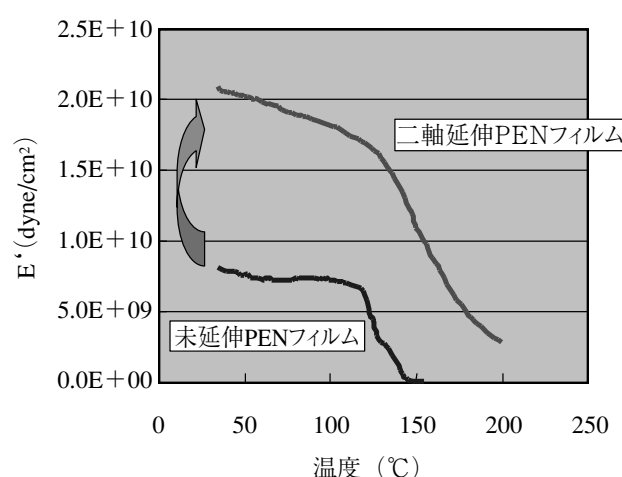

a) 貯蔵弾性率

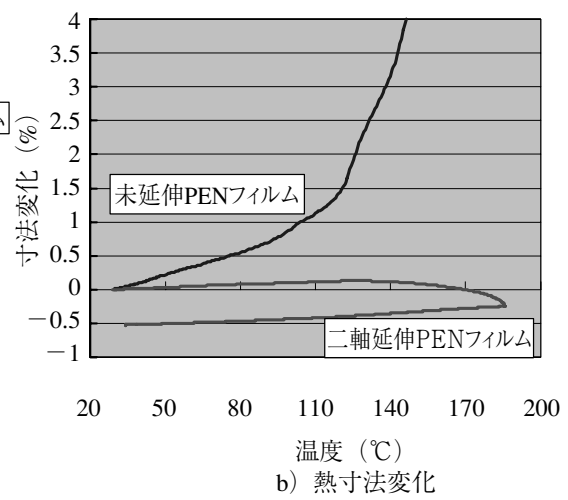

b) 熱寸法変化

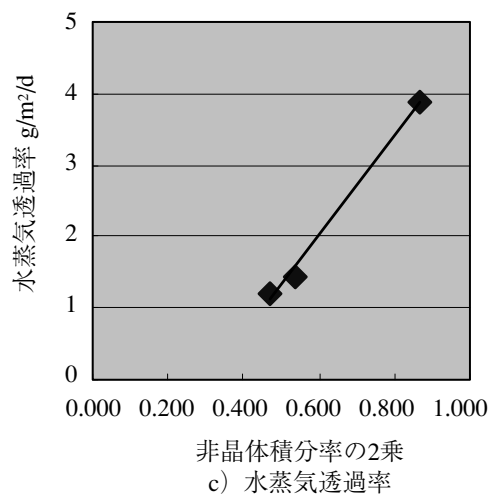

c) 水蒸気透過率

図 2 二軸延伸による物性変化

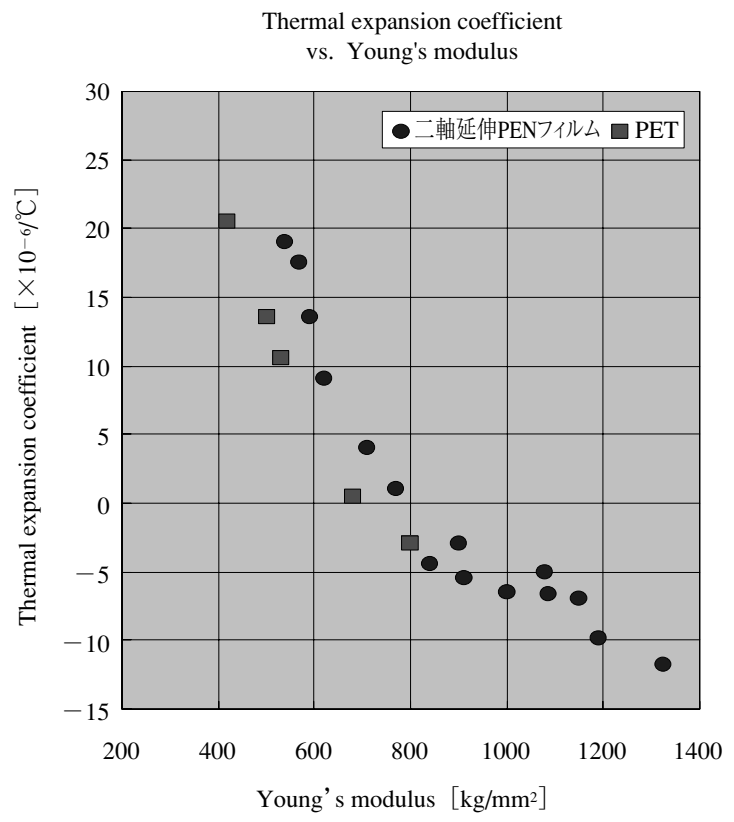

a) 熱膨張係数

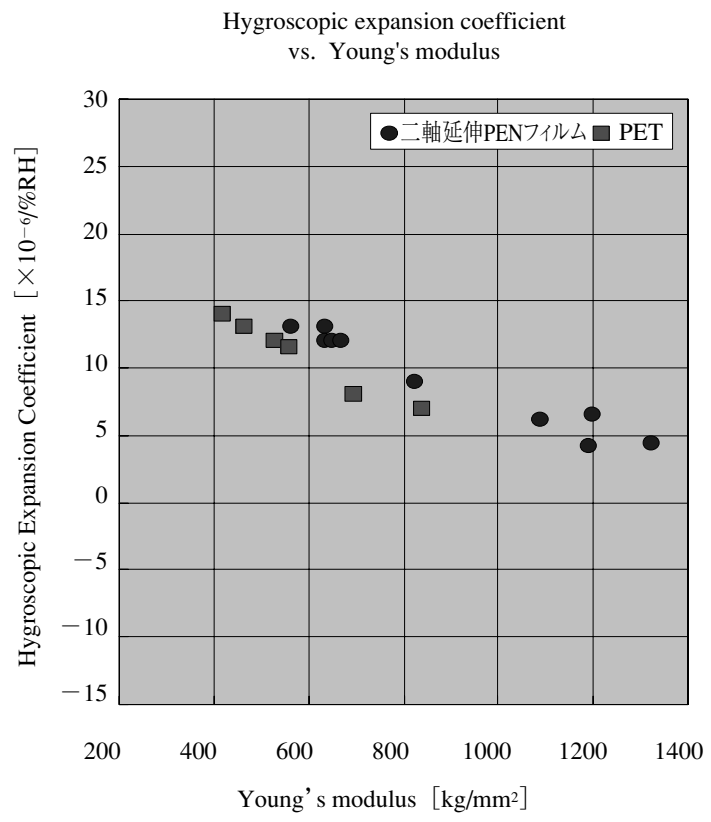

b) 湿度膨張係数

図 3 フィルムのヤング率と膨張率との関係 


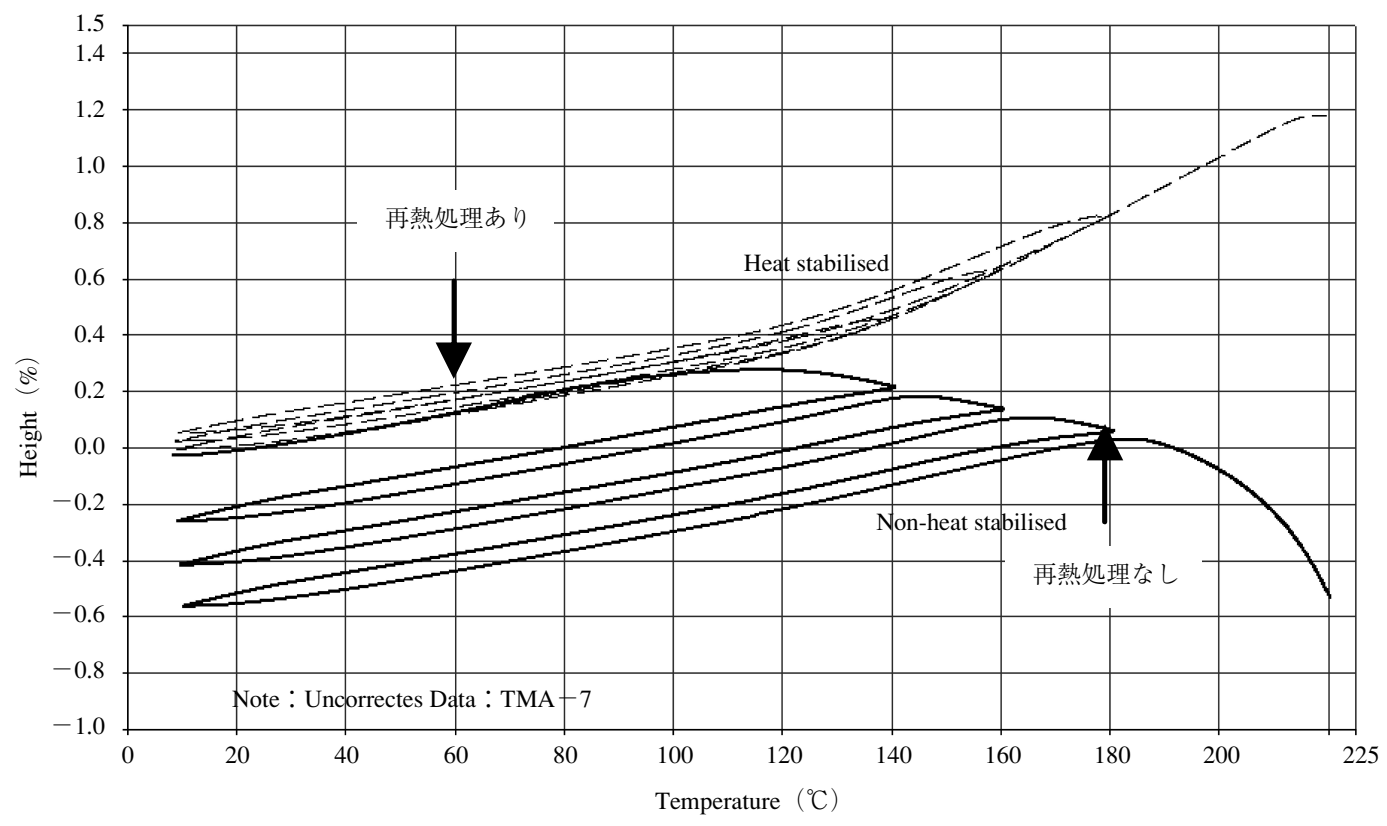

図４ヒートサイクルによる寸法変化挙動

することが可能である. 図 4 はヒートサイクル過程での フィルム面内方向の伸縮挙動であるが，2 軸延伸と再熱処 理の組み合わせにより伸縮がほとんどないレベルを達成す ることができている.

\section{4. 今後の開発動向と課題}

割れにくい，軽い，曲面追随性がある，大量生産に向い ているといった点がガラスと比較したときのフィルムの利 点であると考えられる. プラスチック基板化の狙いは次の 二点が挙げられる. 第一に, より薄く, より軽く, 割れな く,フレキシブル性を持った有機エレクトロニクスデバイ スの開発, 第二に, ロール・トゥ・ロールでの量産製造に よるコストダウン化である.

現状ではガラス基板にプラスチック基板を貼付けるよう なプロセスにて検討されているが，今後はプラスチック基 材に適応したプロセスの開発が期待される。 さらに，プラ スチック基板には今後ますます高度な寸法安定性, 無欠点
性，高透明性，平滑性，带電防止性などが求められるよう になると予想される，さらに，有機エレクトロニクスデバ イスのロール・トゥ・ロールの加工プロセスが実現されれ ば，透明フィルムの市場は飛躍的に広がると期待されるが， そのためには加工工程での反りや伸び，ハンドリングのし やすさなども重要な要素になってくると予想される.

\section{参 考 文 献}

1 ）小山俊也：コンバーテック，366，58（2003）

2 ）伊藤浩志，鞠谷雄士：成形加工，14，287（2002）

3 ) Kawakami, D., Hsiao, Benjamin S., Ran, Shaofeng, Burger, Christian, Fu, Bruce, Sics, Igors, Chu, Benjamin and Kikutani, T. : Polymer, 45, 905 (2004)

4 ）飯田真：高分子学会予稿集，I Pb 040，718（2004）

5 ) 飯田真：透明プラスチックの最前線，高分子学会 編，111（2006） 